\title{
Hubungan antara Pola Menyusui Ibu dengan Gangguan ADHD pada Anak
}

Titis Hadiati

\section{Bagian Psikiatri Fakultas Kedokteran Universitas Diponegoro Semarang}

\begin{abstract}
ABSTRAK
Pendahuluan : Menyusui dikaitkan dengan risiko yang lebih rendah untuk masalah perilaku anak di masa kecil. Ada beberapa penelitian yang menyatakan bahwa attentiondeficit hyperactivity disorder (ADHD) bisa dicegah dengan pemberian ASI (Air Susu Ibu). Dalam pemberian ASI ini ada beberapa pola menyusui yaitu menyusui eksklusif, menyusui predominan, dan menyusui parsial (WHO).

Tujuan : Mengetahui hubungan antara pola menyusui Ibu dengan attentiondeficit hyperactivity disorder (ADHD) pada anak.

Metode : Penelitian analitik, dengan pendekatan cross-sectional. Sampel ibu-ibu dari anak- anak di TK Hidayatullah Semarang yang berumur $4-6$ tahun dan alamat lengkap. Besar sampel sebanyak 71. Alat yang digunakan adalah catatan administrasi murid TK Hidayatullah Semarang selama periode 1 November 2016 - 25 April 2017, Blangko SPPAHI (Skala Penilaian Perilaku Anak Hiperaktif) dan Kuisioner Pola Menyusui Ibu. Uji statistik ini menggunakan sistem komputerisasi SPSS dengan Chi Square Tests dimana taraf signifikansi $(\alpha)$ yang digunakan adalah $5 \%(0,05)$.

Hasil : Terdapat 71 data yang diproses, sehingga tingkat kevalidannya 100\%, yang mengalami ADHD sekitar 11 anak $(15,5 \%)$ dan yang tidak mengalami ADHD sekitar 60 anak (84,5\%). Hasil uji statistik dengan Chi Square Test pada SPSS versi 20 diperoleh hasil nilai $\mathrm{p}=0,444$. Karena nilai $\mathrm{p}$ lebih besar dari 0,05 , sehingga dapat diartikan bahwa antara pola menyusui ibu dengan ADHD pada anak tidak terjadi hubungan yang signifikan atau bermakna dan besarnya nilai koefisien kontingensi (r) adalah 0,149 maka kekuatan korelasi tergolong sangat lemah.

Kesimpulan : ADHD hanya terjadi pada $15,5 \%$ anak yang pernah mendapatkan ASI dengan berbagai macam pola menyusui ibu. Tidak ada hubungan antara pola menyusui Ibu dengan ADHD.
\end{abstract}

Kata Kunci : menyusui, ADHD, ASI, Pola Menyusui, Ibu. 


\section{PENDAHULUAN}

Attention-deficit/ hyperactivity disorder (ADHD) merupakan kelainan neurobehavioral yang paling sering terjadi pada anak-anak, yang juga merupakan suatu keadaan kronis yang paling sering berpengaruh pada anak-anak usia sekolah, dan merupakan gangguan mental yang sering ditemukan pada anakanak. ADHD ditandai oleh 3 gejala utama yaitu inatensi, hiperaktivitas, dan impulsivitas. Angka prevalensi ADHD di dunia sebesar 2\% sampai 9,5\% dari semua anak usia sekolah. Dalam pemberian ASI ini ada beberapa pola menyusui. Dalam laporan Riskesdas, pola menyusui dikelompokkan menjadi tiga kategori, yaitu menyusui eksklusif, menyusui predominan, dan menyusui parsial sesuai definisi WHO. Ada penelitian yang menyatakan bahwa ADHD bisa dicegah dengan pemberian ASI (Air Susu Ibu). Beberapa penelitian menyatakan bahwa ASI melindungi bayi dan anak dari penyakit infeksi dan bisa mencegah anak dari ADHD (attention deficit and hiperactivity disorder) atau GPPH (gangguan pemusatan perhatian dan hiperaktifitas). Berdasarkan uraian di atas maka dilakukan penelitian pola menyusui dengan ADHD

\section{TUJUAN}

Mengetahui hubungan antara pola menyusui Ibu dengan attention-deficit hyperactivity disorder (ADHD) pada anak.

\section{METODE}

Penelitian analitik, dengan pendekatan cross-sectional dengan sampel ibuibu dari anak-anak di TK Hidayatullah Semarang yang berumur $4-6$ tahun saat dilakukan penelitian, ada atau tidak ada ADHD dan alamat lengkap. Besar sampel yang digunakan sebanyak 71. Alat yang digunakan adalah catatan administrasi murid TK Hidayatullah Semarang selama periode 1

November 2016 - 25 April 2017, Blangko SPPAHI (Skala Penilaian Perilaku Anak Hiperaktif) dan Kuisioner Pola Menyusui Ibu yang dibuat untuk keperluan penelitian ini. Uji statistik dalam penelitian ini menggunakan sistem komputerisasi SPSS dengan Chi Square Tests dimana taraf signifikansi $(\alpha)$ yang digunakan adalah $5 \%(0,05)$.

\section{HASIL}

Berdasarkan hasil wawancara di TK Hidayatullah Semarang pada 1 November 2016 - 31 April 2017 didapatkan sebanyak 11 penderita ADHD, dan 60 bukan penderita ADHD dari total 71 ibu-ibu yang menyusui anaknya. Berikut merupakan Distribusi berdasarkan ada tidaknya gangguan ADHD. 
Tabel 1. Distribusi data

\begin{tabular}{lllllll}
\hline & \multicolumn{5}{c}{ Cases } \\
\cline { 2 - 7 } & \multicolumn{2}{c}{ Valid } & \multicolumn{2}{c}{ Missing } & \multicolumn{2}{c}{ Total } \\
\cline { 2 - 4 } & $\begin{array}{l}\text { Persentase } \\
(\boldsymbol{\%})\end{array}$ & Jumlah & $\begin{array}{l}\text { Presentase } \\
(\boldsymbol{\%})\end{array}$ & Jumlah & $\begin{array}{l}\text { Presentase } \\
(\boldsymbol{\%})\end{array}$ \\
\hline $\begin{array}{l}\text { ADHD } \\
\text { (Pola ASI) }\end{array}$ & 71 & 100 & 0 & 0 & 71 & 100 \\
\hline
\end{tabular}

Terlihat dari tabel 1 Terdapat 71 data yang diproses, sehingga tingkat kevalidannya $100 \%$.

Tabel 2. Distribusi penderita berdasarkan ada tidaknya gangguan ADHD

\begin{tabular}{ccccc}
\hline & \multicolumn{4}{c}{ Pola ASI } \\
\cline { 2 - 5 } & Hanya ASI & $\begin{array}{c}\text { ASI+ Air } \\
\text { selain ASI }\end{array}$ & $\begin{array}{c}\text { ASI }+ \\
\text { Sufor/bubur }\end{array}$ & Total \\
\hline ADHD & 6 & 2 & 3 & 11 \\
Tidak ADHD & 39 & 4 & 17 & 60 \\
\hline Total & 45 & 6 & 20 & 71 \\
\hline
\end{tabular}

Terlihat dari tabel 2 yang mengalami gangguan ADHD sekitar 11 anak $(15,5 \%)$ dan yang tidak mengalami gangguan ADHD sekitar 60 anak $(84,5 \%$

\section{Hubungan Pola Menyusui Ibu Dengan Gangguan ADHD pada Anak}

Hasil uji statistik yang menggunakan Chi Square Test pada sistem komputerisasi SPSS versi 20 diperoleh hasil nilai $\mathrm{p}=0,444$. Karena nilai $\mathrm{p}$ lebih besar dari 0,05, sehingga dapat diartikan bahwa antara pola menyusui ibu dengan gangguan ADHD pada anak tidak terjadi hubungan yang signifikan atau bermakna. Berdasarkan hasil penelitian besarnya nilai koefisien kontingensi (r) adalah 0,149 maka kekuatan korelasi tergolong sangat lemah. Jadi bisa dikatakan bahwa hubungan pola menyusui ibu dengan gangguan ADHD pada anak bermakna sangat lemah.

\section{DISKUSI}

Dari hasil penelitian tentang hubungan antara pola menyusui Ibu dengan gangguan ADHD pada anak menemukan bahwa antara pola menyusui Ibu dengan gangguan ADHD tidak terjadi hubungan yang signifikan atau bermakna. Berdasarkan hasil penelitian besarnya nilai koefisien kontingensi (r) adalah 0,149 maka kekuatan korelasi tergolong sangat lemah. Jadi bisa dikatakan bahwa hubungan antara pola menyusui Ibu dengan gangguan ADHD bermakna sangat lemah. Hubungan antara pola menyusui Ibu dengan gangguan ADHD tergolong sangat lemah karena ada beberapa faktor lain yang mempengaruhi gangguan ADHD seperti masalah pada masa neonatus, anak dalam perawatan khusus, dan adanya kekurangan hormon. 
Salah satu penelitian yang dilakukan oleh Subin Park dan kawan-kawan di Korea Selatan, dimana penelitian ini menemukan bahwa kemungkinan terdapat efek perlindungan dari menyusui terhadap perilaku anak dengan mediasi parsial oleh IQ anak, serta terdapat dampak positif dari menyusui pada tingkat kecerdasan di masa anak-anak dengan mediasi parsial oleh permasalahan pemusatan perhatian atau konsentrasi pada anak.

Ada penelitian yang menyatakan bahwa ADHD bisa dicegah dengan pemberian ASI (Air Susu Ibu). Adanya faktor protektif dan nutrient yang sesuai dalam ASI menjamin status gizi bayi baik serta kesakitan dan kematian anak menurun. Beberapa penelitian menyatakan bahwa ASI melindungi bayi dan anak dari penyakit infeksi dan bisa mencegah anak dari ADHD (attention deficit and hiperactivity disorder) atau GPPH (gangguan pemusatan perhatian dan hiperaktifitas).

\section{KESIMPULAN}

Berdasarkan hasil penelitian dapat ditarik kesimpulan bahwa Gangguan ADHD hanya terjadi pada $15,5 \%$ anak yang pernah mendapatkan ASI dengan berbagai macam pola menyusui ibu. Tidak ada hubungan antara pola menyusui Ibu dengan gangguan ADHD.

\section{DAFTAR PUSTAKA}

1. Pusdatin Kemenkes RI.: Situasi dan Analisis ASI Ekslusif. INFODATIN KEMENKES RI; 2014 1-8.

2. Seksi Psikiatri Anak dan Remaja Perhimpunan Dokter Spesialis Kedokteran Jiwa Indonesia.: Pedoman Diagnosis dan Tata Laksana GPPH Gangguan Pemusatan Perhatian dan Hiperaktivitas. Media Aesculapius Fakultas Kedokteran Universitas Indonesia. Jakarta; 2016.

3. Park et al. Nutrition Journal :Protective effect of breastfeeding with regard to children's behavioral and cognitive problems; 2014.p: 13:111

4. Diane et al:: Recalled Initiation and Duration of Maternal Breastfeeding Among Children with and Without ADHD in a Well Characterized CaseControl Sample. Springer; 2015.

5. Soetjiningsih.: Tumbuh Kembang Anak, EGC. Jakarta; 1995.p: 23 - 24. 